\title{
Biochar of Bamboo Influencing the Availability of P From Different Phosphate Sources in Dystrophic Yellow Oxisol of Amazon
}

\author{
Danielle Monteiro de Oliveira ${ }^{1}$, João Batista Dias Damaceno ${ }^{2}$, Ana Cecília Nina Lobato ${ }^{2}$, \\ Rodrigo de Souza Guimarães ${ }^{1}$, José Lavres Júnior ${ }^{3}$, Iraê Amaral Guerrini ${ }^{4} \&$ Newton Paulo de Souza Falcão ${ }^{1}$ \\ ${ }^{1}$ Department of Agronomic Sciences, National Institute of Amazonian Research, Manaus, Brazil \\ 2 Postgraduate Program in Tropical Agronomy, Faculty of Agricultural Sciences, Federal University of \\ Amazonas, Manaus, Brazil \\ ${ }^{3}$ Nuclear Energy Agriculture Center, Piracicaba, Brazil \\ ${ }^{4}$ Paulista State University, Botucatu, Brazil \\ Correspondence: Danielle Monteiro de Oliveira, Department of Agronomic Sciences, National Institute of \\ Amazonian Research, Manaus, Brazil. E-mail: dmoliveira.am@gmail.com
}

Received: March 31, 2019

doi:10.5539/jas.v11n9p242
Accepted: May 1, 2019 Online Published: June 30, 2019

URL: https://doi.org/10.5539/jas.v11n9p242

\begin{abstract}
The residual biomass of leaves and branches of fast returning species, such as bamboo, are the most promising for biochar production, and could be used as an excellent soil conditioner to recuperate degraded areas, stock carbon and recycling nutrients. The experiment was carried out on greenhouse condition as completely randomized design, under a factorial arrangement $(3 \times 3)$, been three pyrolysis condition $\left(400{ }^{\circ} \mathrm{C}, 500{ }^{\circ} \mathrm{C}\right.$ and 600 ${ }^{\circ} \mathrm{C}$ ), applied at $40 \mathrm{tha}^{-1}$ and three phosphate sources: Nature Phosphate (NP), Simple Superphosphate (SS) and Triple Superphosphate (TS) (100 kg ha ${ }^{-1}$ as $\left.\mathrm{P}_{2} \mathrm{O}_{5}\right)$, during one year with four crop rotation of cowpea and corn. The presence of biochar, independently of pyrolysis temperature, allowed value of shoot dry matter highest in the first two crops rotation and the P contents in the soil were increased up to third crop, however, it is showing statistic difference only in the soil after the two cowpea crops, in which the interaction showed similar behavior between the more soluble source (TS) and the less soluble source (NP). The concentrations of foliar P were similar between the two cowpea crops, thus in the corn crops the concentrations of foliar P were higher in the second crop and showed significance in the two crops. The presence of biochar modified the nature behavior of the phosphate sources, becoming similar P availability.
\end{abstract}

Keywords: black carbon, soil fertility, phosphate fertilizers

\section{Introduction}

The maintenance of high levels of stable organic matter and nutrients available in Dark Earth of Indian soils is associated with a large and prolonged incorporation of pyrogenic carbon (Glaser et al., 2001; Lehmann et al., 2002, 2003b). The use of biochar as a physical, chemical and biological conditioner in tropical soils has been motivated by researches developed with Dark Earth coal, which show its importance in the stability of organic matter, in the increase of cation exchange capacity, and in the reduction of acidity and aluminum content toxic to plants (Glaser et al., 2002; Falcão et al., 2003; Van Zwieten et al., 2010; Zornoza et al., 2016). The Biochar may exhibit different physicochemical characteristics and properties depending on the source and the carbonization temperature of the plant material (Bird et al., 2015; Roberts \& Nys, 2016). The biocarbon of bamboo presents a great advantage in relation to that of any other woody species, since it has approximately double the surface area of the biochar and a great quantity of micropores, which give to the bamboo biochar greater adsorption power of solids and gases (Silva, 2005; Xu et al., 2012).

Considering that the high levels of phosphorus $(\mathrm{P})$ found in dark earths are linked to large amounts of organic biocarbonated material over decades (Kern, 2001; Weliton et al., 2011), the hypothesis of this work is that the presence of biochar in the soil can contribute to increase the amount of soluble phosphorus from conventional phosphate fertilizers, increasing the agronomic efficiency of these fertilizers. The high cost of soluble phosphate sources has led producers to become interested in natural phosphate, more specifically natural phosphate (Resende et al., 2006), but which have little agronomic efficiency due to its slow solubilization. 
Biochar may play an important role in $\mathrm{P}$ sorption and desorption processes in the soil and may be a more efficient adsorbent of $\mathrm{P}$ per gram of material than the clay fractions of soils. Coal samples collected from different sites of black soil and at different depths presented different adsorption and desorption properties of $\mathrm{P}$ (Falcão et al., 2003). The results allowed to infer that this coal has the potential to retain significant amounts of solubilized P from mineral fertilizers, thus avoiding its chemical fixation by iron and aluminum oxides and the type 1:1 clays present in high concentrations in tropical soils. The objective of this study was to evaluate the effect of different carbonization temperatures of bamboo on the availability of $\mathrm{P}$ in the soil and in cowpea and corn plants from the application of different phosphate sources.

\section{Material and Methods}

\subsection{Location and Experimental Design}

The experiment was carried out on greenhouse of the Agronomy Departaments in the Campus III of the National Institute of Amazonian Research (INPA), Manaus, Amazonas, Brazil. According to the classification of Köppen (1948), the climate in Manaus is classified in Am (Tropical humid and subhumid) with average temperature of $27.4^{\circ} \mathrm{C}$

The experiment was conducted follow a completely randomized design, in a factorial $(3 \times 3)$. The study factors were: three sources of P (NP-Natural phosphate from ARAD, 33\% total P and 9\% citric acid; SS-Simple Superphosphate, $19 \% \mathrm{P}_{2} \mathrm{O}_{5}$ total and $18 \%$ citric acid and TS-Triple superphosphate, $45 \% \mathrm{P}_{2} \mathrm{O}_{5}$ total and $40 \%$ citric acid) and three carbonization temperatures $\left(400{ }^{\circ} \mathrm{C}, 500{ }^{\circ} \mathrm{C}\right.$ and $\left.600{ }^{\circ} \mathrm{C}\right)$ with nine treatments and four replicates. Samples were collected from the subsurface layer $(20-40 \mathrm{~cm})$ of a soil classified as a distrofic yellow oxisoil (EMBRAPA, 2018), with the chemical characteristics described in Table 1.

Table 1. Chemical characteristics of soil used in experimentation

\begin{tabular}{ll}
\hline Attributes & Soil characteristics \\
\hline $\mathrm{pH}\left(\mathrm{H}_{2} \mathrm{O}\right)$ & 3.2 \\
$\mathrm{pH}\left(\mathrm{CaCl}_{2}\right)$ & 3.7 \\
$\mathrm{Ca}\left(\mathrm{cmol}_{\mathrm{c}} \mathrm{dm}^{-3} / \mathrm{g} \mathrm{kg}^{-1}\right)$ & 5.7 \\
$\mathrm{Mg}\left(\mathrm{cmol}_{\mathrm{c}} \mathrm{dm}^{-3} / \mathrm{g} \mathrm{kg}^{-1}\right)$ & 3.1 \\
$\mathrm{~K}\left(\mathrm{cmol}_{\mathrm{c}} \mathrm{dm}^{-3} / \mathrm{g} \mathrm{kg}^{-1}\right)$ & 1.4 \\
$\mathrm{P}\left(\mathrm{mg} \mathrm{dm}^{-3} / \mathrm{g} \mathrm{kg}^{-1}\right)$ & 2.9 \\
$\mathrm{Fe}\left(\mathrm{mg} \mathrm{dm}^{-3} / \mathrm{mg} \mathrm{kg}^{-1}\right)$ & 139.1 \\
$\mathrm{Zn}\left(\mathrm{mg} \mathrm{dm}^{-3} / \mathrm{mg} \mathrm{kg}^{-1}\right)$ & 3.6 \\
$\mathrm{Al}\left(\mathrm{cmol}_{\mathrm{c}} \mathrm{dm}^{-3}\right)$ & 4.0 \\
\hline
\end{tabular}

\subsection{Preparation of Biochar}

The Biochar was obtained from the carbonization of fresh biomass of bamboo (Bambusa vulgaris "vittata") in furnace under three temperatures $\left(400{ }^{\circ} \mathrm{C}, 500{ }^{\circ} \mathrm{C}\right.$ and $\left.600{ }^{\circ} \mathrm{C}\right)$. In the production of the biochar was used a refractory brick oven with a capacity of $20 \mathrm{~kg}$ at INPA. With removal of the carbonization temperatures $\left(400{ }^{\circ} \mathrm{C}\right.$, $500{ }^{\circ} \mathrm{C}$ and $600{ }^{\circ} \mathrm{C}$ ), the residence time of the material was about 30 minutes, followed by 24 hours of standing to cool and be withdrawn. Subsequently, the materials were sieved in a $2.00 \mathrm{~mm}$ mesh and subjected to chemical attributes analysis, using a standardized methodology for the analysis of organic material (Embrapa, 2011) (Table 2).

Table 2. Biochar chemical characteristics produced from Bamboo (Bambusa vulgaris "vittata") according to pyrolysis temperatures $\left(400{ }^{\circ} \mathrm{C}, 500^{\circ} \mathrm{C}\right.$ and $\left.600^{\circ} \mathrm{C}\right)$.

\begin{tabular}{|c|c|c|c|c|c|c|c|c|c|}
\hline Biochar of Bamboo & $\mathrm{pH}_{\left(\mathrm{H}_{2} \mathrm{O}\right)}$ & $\mathrm{Ca}$ & $\mathrm{Mg}$ & $\mathrm{K}$ & $\mathrm{P}$ & $\mathrm{Fe}$ & $\mathrm{Zn}$ & $\mathrm{Mn}$ & $\mathrm{Cu}$ \\
\hline & & \multicolumn{3}{|c|}{------- $\mathrm{cmol}_{\mathrm{c}} \mathrm{kg}^{-1}$} & \multicolumn{5}{|c|}{ 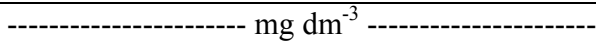 } \\
\hline $400^{\circ} \mathrm{C}$ & 10.4 & 0.34 & 0.56 & 17.36 & 171.19 & 10.9 & 3.3 & 9.2 & 1.2 \\
\hline $500^{\circ} \mathrm{C}$ & 10.2 & 0.37 & 0.62 & 12.48 & 132.42 & 10 & 2.3 & 11.1 & 0.7 \\
\hline $600^{\circ} \mathrm{C}$ & 10.1 & 0.26 & 1.06 & 8.31 & 115.36 & 9.2 & 5.7 & 13.9 & 1.3 \\
\hline
\end{tabular}

2.3 Experimental Conditions and Analysis 
Two rotation cycles with cowpea (Vigna unguiculata L. Walp) and two with corn (Zea mays) were used in pots with a capacity of $3 \mathrm{~kg}$ of soil. The amount of fertilizer applied before each rotation cycle as a complementary was $90 \mathrm{~kg} \mathrm{ha}^{-1}$ of urea; $120 \mathrm{~kg} \mathrm{ha}^{-1}$ of potassium chloride. The treatments of phosphorus fertilization were $326 \mathrm{~kg}$ $\mathrm{ha}^{-1}$ natural phosphate from ARAD; $555 \mathrm{~kg} \mathrm{ha}^{-1}$ of single superphosphate; $222 \mathrm{~kg} \mathrm{ha}^{-1}$ of triple superphosphate. The amount of phosphate were $100 \mathrm{~kg} \mathrm{ha}^{-1}$ of $\mathrm{P}_{2} \mathrm{O}_{5}$, this applied amount of $\mathrm{P}_{2} \mathrm{O}_{5}$ ha $^{-1}$ is equivalent to a $22.22 \mathrm{mg}$ $\mathrm{kg}^{-1}$ of $\mathrm{P}$ for all sources of phosphorus used, and $40 \mathrm{t} \mathrm{ha}^{-1}$ of biochar $(2.00 \mathrm{~mm}$ diameter $)$ both in a single application.

Cultures were performed at intervals of approximately 30 days and after each cultivation the soil was cleared for root withdrawal. The plants were harvested at 45 days after germination. Samples were processed in the laboratory to determine the dry mass of the aerial part and the concentration of $\mathrm{P}$. Representative soil samples was colected at the same time of the crop havest for determination of the $\mathrm{pH}$ values in $\mathrm{CaCl}_{2}$ (active acidity) $\mathrm{CaCl}_{2} 0.01 \mathrm{~mol} \mathrm{~L}^{-1}$. Phosphorus contents by means of the ion exchange resin method (Raij et al., 2001), titratable exchange aluminum $\left(\mathrm{KCl} 1 \mathrm{~mol} \mathrm{~L}^{-1}\right)$ and $\mathrm{H}+\mathrm{Al}$ (potential acidity).

\subsection{Statistical Analysis}

Data were submitted to analysis of variance using the statistical program ASSISTAT 7.7 beta. When the significance was determined using the F test, we compared the means by the Tukey test at the 5\% probability level.

\section{Results}

In the first cultivation of cowpea, the aerial dry mass (ADM), in the treatment that received biochar produced under the temperature of $400{ }^{\circ} \mathrm{C}$ plus simple superphosphate (SS), presented higher value without, however, presenting a significant difference in relation to the treatment received (NP), this result may be a reflection of the calcium and sulfur supply through the application of simple superphosphate. On the other hand, the treatment that received the most soluble source (triple superphosphate-TS) presented the lowest production of MSPA (Table 2). The ADM production of the bean plants that received biochar produced at $500{ }^{\circ} \mathrm{C}$ increased with supply of the P sources in the following order TS $=$ NP $>$ SS.

On the other hand, in the treatments that received biochar produced at $600{ }^{\circ} \mathrm{C}$ the ADM was higher in the treatment with FSS that showed a significant difference in relation to the treatment with natural phosphate. Analyzing the sources of phosphorus, it can be observed that the plants of the treatments that received bamboo biomass biochar produced at $500{ }^{\circ} \mathrm{C}$ and $600{ }^{\circ} \mathrm{C}$ with NP and TS presented similar ADM production (Table 2). 
Table 2. Dry shoot mass, $\mathrm{P}$ foliar concentration and $\mathrm{P}$ content in the soil after each sequential cultivation of cowpea and maize as a function of bamboo carbonization temperature for biochar and $\mathrm{P}$ sources (Natural Phosphate-NP, Superphosphate Simple-SS, triple superphosphate-TS) in typical dystrophic Yellow Oxisol under greenhouse conditions in Manaus, AM, between 2011 and 2012.

\begin{tabular}{|c|c|c|c|c|c|c|c|c|c|}
\hline \multirow{2}{*}{ Biocarbonization Temperatures } & \multicolumn{3}{|c|}{ Aerial Dry Mass } & \multicolumn{3}{|c|}{ Foliar concentration $\mathrm{P}$} & \multicolumn{3}{|c|}{$\mathrm{P}$ content in soil } \\
\hline & NP & SS & TS & NP & SS & TS & NP & $\mathrm{SS}$ & TS \\
\hline & \multicolumn{3}{|c|}{ 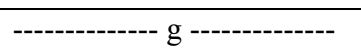 } & \multicolumn{3}{|c|}{-------- g kg $^{-1}$--------- } & \multicolumn{3}{|c|}{ 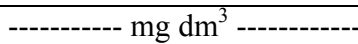 } \\
\hline \multicolumn{10}{|c|}{$1^{\text {st }}$ cultivation of cowpea (Vigna unguiculata) } \\
\hline $400^{\circ} \mathrm{C}$ & $6.93^{\mathrm{aA}}$ & $7.27^{\mathrm{aA}}$ & $5.70^{\mathrm{bB}}$ & 2.73 & 3.14 & 3.03 & $11.25^{\mathrm{aA}}$ & $10.75^{\mathrm{aA}}$ & $10.50^{\mathrm{bA}}$ \\
\hline $500^{\circ} \mathrm{C}$ & $6.62^{\mathrm{aA}}$ & $6.08^{\mathrm{aB}}$ & $6.62^{\mathrm{aA}}$ & 2.79 & 3.40 & 3.51 & $11.00^{\mathrm{aB}}$ & $11.50^{\mathrm{aB}}$ & $13.50^{\mathrm{aA}}$ \\
\hline $600^{\circ} \mathrm{C}$ & $6.15^{\mathrm{aA}}$ & $6.25^{\mathrm{aB}}$ & $6.18^{\mathrm{aAB}}$ & 3.24 & 2.82 & 3.52 & $11.50^{\mathrm{aA}}$ & $10.75^{\mathrm{aA}}$ & $11.50^{\mathrm{bA}}$ \\
\hline \multicolumn{10}{|l|}{$1^{\text {st }}$ cultivation of maize (Zea mays) } \\
\hline $400^{\circ} \mathrm{C}$ & 5.73 & 5.75 & 5.86 & $0.66^{\mathrm{bA}}$ & $0.66^{\mathrm{aA}}$ & $0.63^{\mathrm{bA}}$ & 14.25 & 10.25 & 13.00 \\
\hline $500^{\circ} \mathrm{C}$ & 5.62 & 5.66 & 5.66 & $1.39^{\mathrm{aA}}$ & $0.69^{\mathrm{aB}}$ & $1.39^{\mathrm{aA}}$ & 11.50 & 12.00 & 13.50 \\
\hline $600^{\circ} \mathrm{C}$ & 5.85 & 5.81 & 6.07 & $0.77^{\mathrm{bA}}$ & $0.72^{\mathrm{aA}}$ & $0.88^{\mathrm{bA}}$ & 13.00 & 11.50 & 15.25 \\
\hline \multicolumn{10}{|c|}{$2^{s t}$ cultivation of cowpea (Vigna unguiculata) } \\
\hline $400^{\circ} \mathrm{C}$ & $10.81^{\mathrm{aA}}$ & $7.55^{\mathrm{aB}}$ & $10.11^{\mathrm{aA}}$ & 2.29 & 2.31 & 2.25 & $13.50^{\mathrm{aA}}$ & $10.25^{\mathrm{bB}}$ & $15.25^{\mathrm{aA}}$ \\
\hline $500^{\circ} \mathrm{C}$ & $10.07^{\mathrm{aA}}$ & $8.68^{\mathrm{aAB}}$ & $7.56^{\mathrm{bB}}$ & 2.15 & 2.14 & 2.42 & $13.25^{\mathrm{aA}}$ & $13.75^{\mathrm{aA}}$ & $14.25^{\mathrm{aA}}$ \\
\hline $600^{\circ} \mathrm{C}$ & $7.70^{\mathrm{bA}}$ & $7.61^{\mathrm{aA}}$ & $7.61^{\mathrm{bA}}$ & 2.45 & 2.06 & 2.25 & $12.25^{\mathrm{aAB}}$ & $11.50^{\mathrm{bB}}$ & $13.75^{\mathrm{aA}}$ \\
\hline \multicolumn{10}{|c|}{$2^{s t}$ cultivation of maize (Zea mays) } \\
\hline $400^{\circ} \mathrm{C}$ & 4.00 & 3.29 & 3.83 & $2.03^{\mathrm{aA}}$ & $1.75^{\mathrm{bA}}$ & $2.13^{\mathrm{aA}}$ & 8.00 & 8.00 & 9.50 \\
\hline $500{ }^{\circ} \mathrm{C}$ & 4.17 & 4.47 & 4.44 & $1.99^{\mathrm{aA}}$ & $2.16^{\mathrm{bA}}$ & $2.08^{\mathrm{aA}}$ & 10.00 & 9.50 & 10.00 \\
\hline $600{ }^{\circ} \mathrm{C}$ & 4.75 & 4.07 & 4.23 & $2.21^{\mathrm{aB}}$ & $3.01^{\mathrm{aA}}$ & $1.99^{\mathrm{aB}}$ & 8.00 & 7.75 & 8.00 \\
\hline
\end{tabular}

Note. Case-sensitive, followed by the same letter in the row and in the column respectively, do not differ statistically from each other by the Tukey test $5 \%$.

In the soil collected after the first cultivation of cowpea in the treatments that received the biochar produced at a temperature of $400{ }^{\circ} \mathrm{C}$, the $\mathrm{P}$ contents were higher in the treatment with natural phosphate, however, there was no significant difference in relation to the other sources of phosphate. It was observed that phosphorus sources (NP $<\mathrm{SS}<\mathrm{TS}$ ) with $0.75 \mathrm{mg} \mathrm{dm}$ of phosphorus plus natural phosphate were present in the soil and in the treatments with biochar produced at $500{ }^{\circ} \mathrm{C}$, the phosphorus content increased as a function of the solubility of the sources phosphates, significant differences with higher content of application of triple superphosphate.

This result may be related to the less condensed structures of $\mathrm{C}$ found in the of lower biocarbonization temperatures, which increases the reactivity and may have influenced the behavior of the natural phosphate, resulting in greater availability of phosphorus than the more soluble sources (Keiluweit et al., 2010). Moreover, in the treatments with triple superphosphate, it is noticed that the presence of biochar produced at $500{ }^{\circ} \mathrm{C}$ showed higher phosphorus content with significant difference in relation to the temperature of $400{ }^{\circ} \mathrm{C}$ and $600{ }^{\circ} \mathrm{C}$, which presented higher contents, however, the $\mathrm{pH}$ values showed no significant difference.

It was observed that in the treatments that received biochar produced at $600{ }^{\circ} \mathrm{C}$, soil $\mathrm{P}$ contents did not differ significantly considering the applied sources, it is possible that biochar interfered with the availability of $\mathrm{P}$, resulting in similar behavior regardless of the degree of solubility of the source, since the pH values also did not present a significant difference, even with $\mathrm{pH}$ increase in relation to the soil $\mathrm{pH}$ values at the beginning of the experiment (Table 2). Although no significant difference was observed in $\mathrm{pH}, \mathrm{Al}$ and $\mathrm{H}+\mathrm{Al}$ values, it was observed that in the treatments that received biochar produced at $500{ }^{\circ} \mathrm{C}$, Al levels were lower, regardless of the source of phosphorus, in relation to the others temperatures (Table 3 ). 
Table 3. Values of $\mathrm{pH}, \mathrm{Al}$ and $\mathrm{H}+\mathrm{Al}$ in the soil after each sequential cultivation of cowpea and maize as a function of the carbonization temperature of bamboo for biochar and of the sources of P (natural phosphate-NP, single superphosphate-SS, superphosphate triple-TS) in pots with typical dystrophic Yellow Oxisol in a greenhouse in Manaus, AM, between 2011 and 2012

\begin{tabular}{|c|c|c|c|c|c|c|c|c|c|}
\hline \multirow{2}{*}{ Biocarbonization Temperatures } & \multicolumn{3}{|c|}{$\mathrm{pH} \mathrm{ClCa}_{2}$} & \multicolumn{3}{|c|}{$\mathrm{Al}^{3+}$} & \multicolumn{3}{|c|}{$\mathrm{H}+\mathrm{Al}$} \\
\hline & NP & SS & TS & NP & $\mathrm{SS}$ & TS & NP & SS & TS \\
\hline & \multicolumn{3}{|c|}{ 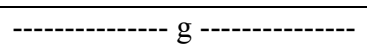 } & \multicolumn{3}{|c|}{-------- g kg $^{-1}$} & \multicolumn{3}{|c|}{ 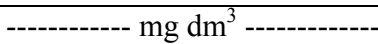 } \\
\hline \multicolumn{10}{|c|}{$1^{\text {st }}$ cultivation of cowpea (Vigna unguiculata) } \\
\hline $400^{\circ} \mathrm{C}$ & 4.14 & 4.06 & 4.12 & 2.40 & 2.00 & 2.00 & 30.40 & 34.20 & 32.60 \\
\hline $500^{\circ} \mathrm{C}$ & 4.30 & 4.20 & 4.24 & 1.00 & 1.00 & 1.00 & 29.60 & 32.80 & 35.00 \\
\hline $600^{\circ} \mathrm{C}$ & 4.12 & 4.06 & 4.02 & 1.60 & 1.60 & 2.00 & 33.00 & 37.20 & 40.60 \\
\hline \multicolumn{10}{|l|}{$1^{\text {st }}$ cultivation of maize (Zea mays) } \\
\hline $400^{\circ} \mathrm{C}$ & 4.28 & 4.30 & 4.22 & 1.00 & 1.40 & 1.60 & 36.60 & 36.00 & 34.40 \\
\hline $500^{\circ} \mathrm{C}$ & 4.40 & 4.40 & 4.34 & 1.00 & 1.00 & 1.00 & 32.60 & 33.40 & 35.00 \\
\hline $600^{\circ} \mathrm{C}$ & 4.22 & 4.28 & 4.18 & 1.20 & 1.20 & 1.40 & 37.40 & 37.80 & 34.80 \\
\hline \multicolumn{10}{|c|}{$2^{\text {st }}$ cultivation of cowpea (Vigna unguiculata) } \\
\hline $400^{\circ} \mathrm{C}$ & $3.96^{\mathrm{bA}}$ & $4.02^{\mathrm{aA}}$ & $3.92^{\mathrm{abA}}$ & 3.00 & 3.80 & 3.20 & 39.80 & 38.00 & 38.40 \\
\hline $500^{\circ} \mathrm{C}$ & $4.10^{\mathrm{aA}}$ & $3.98^{\mathrm{aB}}$ & $4.00^{\mathrm{aAB}}$ & 2.00 & 2.40 & 2.20 & 33.60 & 34.60 & 36.00 \\
\hline $600^{\circ} \mathrm{C}$ & $3.96^{\mathrm{bA}}$ & $3.94^{\mathrm{aA}}$ & $3.82^{\mathrm{bB}}$ & 3.00 & 3.20 & 3.80 & 34.60 & 37.20 & 41.00 \\
\hline \multicolumn{10}{|l|}{$2^{s t}$ cultivation of maize (Zea mays) } \\
\hline $400^{\circ} \mathrm{C}$ & 4.04 & 3.96 & 3.84 & 4.20 & 4.80 & 3.80 & $30.40^{\mathrm{aA}}$ & $34.20^{\mathrm{aA}}$ & $32.20^{\mathrm{aA}}$ \\
\hline $500{ }^{\circ} \mathrm{C}$ & 4.14 & 4.04 & 3.90 & 1.40 & 2.00 & 2.20 & $39.00^{\mathrm{aA}}$ & $25.60^{\mathrm{aB}}$ & $28.60^{\mathrm{aB}}$ \\
\hline $600{ }^{\circ} \mathrm{C}$ & 3.90 & 3.76 & 3.72 & 3.20 & 3.40 & 4.00 & $31.60^{\mathrm{aA}}$ & $34.80^{\mathrm{aA}}$ & $33.40^{\mathrm{aA}}$ \\
\hline
\end{tabular}

Note. Case-sensitive, followed by the same letter in the row and in the column respectively, do not differ statistically from each other by the Tukey test $5 \%$.

The significant results presented for the variables of MSPA and P content available in the first cowpea crop were not observed in the first maize crop, however, leaf $\mathrm{P}$ showed significance (Table 2). It was observed that in the treatments that received biochar produced at $400{ }^{\circ} \mathrm{C}, 500{ }^{\circ} \mathrm{C}$ and $600{ }^{\circ} \mathrm{C}$ with the least soluble source (natural phosphate) and the most soluble source (triple superphosphate), leaf concentrations of $\mathrm{P}$ did not show significant differences between, indicating that the biochar may have acted to equalize the uptake of P by the plants of the different sources, by the adsorption and desorption process of P (Morales et al., 2013).

Although foliar concentration of $\mathrm{P}$ showed significant differences, considering the mineral nutrition, the foliar concentrations of $\mathrm{P}$ observed remained below the appropriate range for the species $\left(2.5\right.$ to $\left.4.0 \mathrm{~g} \mathrm{~kg}^{-1}\right)$ (Malavolta, 2006). For $\mathrm{pH}$ values, $\mathrm{Al}$ and $\mathrm{H}+\mathrm{Al}$, the behavior was similar to the values obtained in the soil of the first cowpea crop, which may be a reflection of the corrective effect of the biochar after 2 cultures, since the original $\mathrm{pH}$ was of 3,7 .

In the second cowpea cultivation (Table 2), ADM increased in the treatments that received biochar produced at $400{ }^{\circ} \mathrm{C}$ with natural phosphate and triple superphosphate in relation to the treatment with single superphosphate. It was concluded that the presence of biochar facilitated the availability of phosphorus even though it comes from sources with different degrees of solubility. In the treatments that received biochar produced at $500{ }^{\circ} \mathrm{C}$, it was verified that the less soluble source (natural phosphate) promoted a significant increase of ADM in relation to the treatment that received the most soluble source.

The available $\mathrm{P}$ content in the soil in this second cowpea crop did not show a significant difference between the different phosphorus sources, regardless of the carbonization temperature, indicating that the biochar may have acted on the availability of $\mathrm{P}$, either in increasing availability from natural phosphate or in reducing or regulating availability with triple superphosphate (Table 2).

It was verified that being the simple superphosphate a more soluble source than the natural phosphate, in the treatments that received the biochar produced at $400{ }^{\circ} \mathrm{C}$ and $600{ }^{\circ} \mathrm{C}$ the levels of $\mathrm{P}$ in the soil were smaller, when compared to the treatments with natural phosphate in this second culture. However, in the treatments with biochar produced at $500{ }^{\circ} \mathrm{C}$ this behavior was not observed, indicating that this temperature can act in order to make the sources with different degrees of solubility with similar behavior in the availability of phosphorus. Rajkovich et al. (2012), mentioned that the physical characteristics, such as the high amount of macro and 
micropores formed at this temperature and chemistry as the formation of functional groups that are influenced by the carbonization temperature.

The highest phosphorus levels were observed in the treatments that received triple superphosphate, regardless of the biocarbonization temperatures, but were statistically the same as the natural phosphate treatments, even with the $\mathrm{pH}$ values showing a significant difference only when applied biochar produced at $600{ }^{\circ} \mathrm{C}$. The presence of biochar produced at $400{ }^{\circ} \mathrm{C}$ and $600{ }^{\circ} \mathrm{C}$ showed a significant difference for the treatments with simple superphosphate with lower available phosphorus levels, although the Al contents were not significant, it was observed that in the treatments that received biochar under a temperature of $500{ }^{\circ} \mathrm{C}$ there was a reduction of contents of $\mathrm{Al}$ in relation to the treatments with temperature of $400{ }^{\circ} \mathrm{C}$ and $600{ }^{\circ} \mathrm{C}$. In general, we have seen that this third crop had a reduction in $\mathrm{pH}$ values and increase in $\mathrm{Al}$ content when compared to previous cultures.

At the same way as the first cultivation of this rotation, $\mathrm{P}$ concentrations in the leaves during the second cowpea crop showed no significant difference $(\mathrm{p}>0.05)$. The same results was observed for ADM variables and P content in the soil during the second crop that did not altered. In the other hand, the concentrations of $\mathrm{P}$ in maize leaves were influenced by treatments in both the first and second crops. In the second maize crop was a significant difference in the $\mathrm{H}+\mathrm{Al}$ content, showing the lowest levels in the treatments with biochar produced at $500{ }^{\circ} \mathrm{C}$. The lack of significance in the weight of the ADM as a function of the treatments can be explained in part by the increase of the soil acidity, as well as the decrease of $\mathrm{P}$ available in the soil.

By analyzing leaf $\mathrm{P}$ concentrations as a function of the lower and higher biocarbonization temperature in this second maize crop, it was observed that treatments that received natural phosphate and single superphosphate resulted in increased foliar P concentrations whil those that received triple superphosphate decreased. In Table 2, it can be seen that the concentrations of $\mathrm{P}$ in maize showed no difference between the sources used, probably due to the presence of biochar, except in the treatments that received biochar produced at $600{ }^{\circ} \mathrm{C}$ where as the simple superphosphate resulted in a higher concentration of $\mathrm{P}$ in the plants, even after the four successive cycles.

\section{Discussion}

The result that may be considered the most relevant in this study was the way in which the different sources behaved in the presence of biochar. It is observed that, although the availability of $\mathrm{P}$ in the soil decreased with successive crops, the presence of the biochar increased the availability of $\mathrm{P}$ from the different phosphate sources. Nemati (2015) described the ability of the biochar to regulate by physical adsorption the availability of nutrients.

The contents and composition of the nutrients present in the biochar vary depending on the sources used, while the carbonization temperature has an effect on the surface properties of the biochar produced (Chan \& Xu, 2009; Zimmerman, 2010; Gautam et al., 2014).

It is observed that the biochar affected the $\mathrm{P}$ availability of the phosphate sources, resulting in different behavior when the sources of $\mathrm{P}$ act in the absence of biochar which highter growth of the plants in the treatments that received the most soluble sources. Lehmann et al. (2003a) found an increase in the ADM of rice and beans by $17 \%$ and $43 \%$, with application of biochar doses of 68 and $135 \mathrm{t} \mathrm{C} \mathrm{ha}^{-1}$, respectively, attributing this growth to the capacity that the biochar presents as a chemical conditioner of the soil, increasing the availability of $\mathrm{P}, \mathrm{K}$ and $\mathrm{Cu}$ from other sources. Other studies have attributed higher plant growth to positive changes in soil biogeochemistry resulting from biochar additions (Lehmann et al., 2003b; Van Zwieten et al., 2010).

The weight of the ADM obtained in the first cowpea crop that received biochar produced at $400{ }^{\circ} \mathrm{C}$ can be explained by the characteristics obtained by the biochar during the low temperature biocarbonization $\left(<550{ }^{\circ} \mathrm{C}\right)$, resulting in a biochar with high soil reactivity and high recovery rate of $\mathrm{C}, \mathrm{N}, \mathrm{K}$ and $\mathrm{S}$, contributing to soil fertility (Steinbeiss et al., 2009; Keiluweit et al., 2010). In addition, this result may also have occurred due to the physical and chemical characteristics of ST and FN in which ST presented a higher degree of dissolution and solubilization and, possibly, a greater fixation of the $\mathrm{P}$ in solution with the iron and aluminum oxides, hydroxides and clay minerals such as kaolinite. It can be inferred that the application of biochar produced at a temperature of $400{ }^{\circ} \mathrm{C}$ did not interfere in this behavior, perhaps because of the lower porosity acquired with the lower pyrolysis temperature (Downie et al., 2009).

The ADM was lower in the first harvest crop cowpea compared to the second crop, and this effect may be related to the higher sorption of the phosphorus by biochar, not ocurring in the second crops out the desorption of the nutrients (Morales et al., 2013). Based on results we can inferred that an increase of $100{ }^{\circ} \mathrm{C}$ in the bamboo biocarbonization may provide changes in the physical and chemical properties of the biochar produced, directly reflecting the dynamics of the nutrients from the applied fertilizers. High temperature pyrolysis produces, in general, high surface area biochar $\left(>400 \mathrm{~m}^{2} \mathrm{~g}^{-1}\right)$ (Downie et al., 2009; Keiluweit et al., 2010), highly aromatic 
and therefore very recalcitrant to decomposition (Sign \& Cowie, 2008), and is considered good adsorbent (Mituza et al., 2004; Lima \& Marshall, 2005), of cationic and anionic charges (Morales et al., 2013).

Although the $\mathrm{P}$ of foliar concentration in cowpea did not indicate a direct relation with the weight of the ADM and $\mathrm{P}$ availability in the soil, considering that the nutrient did not interfere directly in the development of the plant, the foliar $\mathrm{P}$ concentrations did not present significant differences $(\mathrm{p}<0.05)$. All treatments presented the $\mathrm{P}$ leaves concentration above the range considered adequate for the species (from 1.2 to $1.5 \mathrm{~g} \mathrm{~kg}^{-1}$ ) (Malavolta, 2006). The fact that phosphorus sources with different degrees of solubility exhibited similar behavior with the presence of the biochar produced at a temperature of $600^{\circ} \mathrm{C}$ may have occurred due to the large amount of micro or even nanopores and larger surface area of the (Silva, 2005), causing greater physical adsorption of the available phosphorus from the more soluble source (triple superphosphate).

As the soil is a heterogeneous system formed with clay minerals, organic matter and nutrients it is possible that applied biochar in the soil can also adsorb phosphate and nitrate by means of bonding bridge using residual charge of electrostatic attraction or also forming bridges of binders with cations such as $\mathrm{Ca}^{2+}$ and $\mathrm{Mg}^{2+}$ or other metals, including $\mathrm{Al}^{3+}$ and $\mathrm{Fe}^{3+}$ (Mukherjee et al., 2011). Pergeron et al. (2012) report that the most important changes in the physicochemical characteristics of the coal occurred when the carbonization temperatures were between $450{ }^{\circ} \mathrm{C}$ and $650{ }^{\circ} \mathrm{C}$. The increase in the percentage of $\mathrm{C}$, and the decreases in the percentage of $\mathrm{O}$ and $\mathrm{H}$ in this range are indicative of increase in the aromatic structure and gradual change generating graphite.

Based on degree of solubility of the applied sources and the characteristics of the biochar produced, it can be inferred that in the treatments that received the natural phosphate, the biochar had contributed to reduce the adsorption of the available $\mathrm{P}$ by the clay minerals, iron oxides and aluminum present in acid soils (Resende, 2006). The hypothesis that the biochar was responsible for the residual effect of triple superphosphate observed in the second cowpea crop is based on the fact that this behavior is not a characteristic of the phosphate source, which has high reactivity but low residual effect (Raij, 2011). On the other hand, the treatments that received the natural phosphate presented levels of available $\mathrm{P}$ similar to the treatments with triple superphosphate, independent of the temperature of biocarbonization, suggesting that the high residual effect of the natural phosphate (Resende, 2006) decreased, in addition, it observed the increase of soil P contents in this second cowpea crop.

Considering the availability of phosphorus from differents sources, it can be inferred that the presence of the biochar has reduced the rapid reaction of the triple superphosphate in the soil, possibly by adsorbing and making the nutrient available more slowly and increasing the residual effect of this source. Wang et al. (2013) showed that the effect of $\mathrm{P}$ availability on biochar can be influenced by the $\mathrm{P}$ content present in the material, even at low concentrations such as bamboo biochar. Coal samples collected from different sites of black soil and at different depths presented different sorption and desorption properties of P (Falcão et al., 2003), these results allowed permited infer that this coal has the potential to retain significant amounts of solubilized $\mathrm{P}$ from mineral fertilizers, thus avoiding its chemical fixation by iron and aluminum oxides and type 1:1 clays present in high concentrations in tropical soils.

In general, the beans responded more efficiently to the treatments when compared to corn, which is an extremely nutrient demanding plant, especially in $\mathrm{N}$ and $\mathrm{S}$, and, unlike beans, does not have $\mathrm{N}$ absorption strategies, such as biological fixation of N (Malavolta et al., 2006). Major et al. (2010) evaluating application of up to $20 \mathrm{tha}^{-1} \mathrm{of}$ biofuels from kitchen waste in Colombian Savana acid soils, found a decrease in maize yield only in the fourth crop and attributed to the decline in the $\mathrm{Ca}$ and $\mathrm{Mg}$ stock in the soil.

\section{Conclusions}

The treatments that received biochar produced at $500{ }^{\circ} \mathrm{C}$ presented lower levels of exchangeable aluminum, reflecting in higher $\mathrm{pH}$ values when compared to the other temperatures in the four cultures. Biochar increased the agronomic efficiency of natural phosphate in the short term in relation to single superphosphate and triple superphosphate. With application of biochar produced at a temperature of $400{ }^{\circ} \mathrm{C}$, treatments with natural phosphate resulted in higher $\mathrm{P}$ contents in the soil than the treatments with triple superphosphate after the first bean cultivation and the first maize crop and similar contents after the third and fourth cultivations. The residual effect of triple superphosphate after 12 months of application occurred due to the presence of biochar. The levels of phosphorus in the soil with simple superphosphate were higher where biochar produced at $500{ }^{\circ} \mathrm{C}$ was applied in relation to the other temperatures during the four cultures.

\section{Acknowledgements}

FAPEAM, INPA, CENA-USP, Dr. Charles Roland Clement. 


\section{References}

Antal, M. J., \& Grønli, M. (2003). The art, science, and technology of charcoal production. Industrial \& Engineering Chemistry Research, 42(8), 1619-1640. https://doi.org/10.1021/ie0207919

Araujo, I. B., Resende, A. V., Furtini Neto, A. E., Alves, V. M. C., \& Santos, J. Z. L. (2003). Eficiência Nutricional do Milho em Resposta a Fontes e Modos de Aplicação de Fósforo. Revista Ceres, 50(1), 27-39.

Bird, M. I., Wynn, J. G., Saiz, G., Wurster, C. M., \& Mcbeath, A. (2015). The pyrogenic carbon cycle. 43. Annual Review of Earth and Planetary Sciences, 43(1), 273-298. https://doi.org/10.1146/annurev-earth060614-105038

Braga, G. (2006). Eficiência de fosfatos com solubilidade variável em água em solos com capacidade de fixação de fósforo induzida (Doctoral thesis, School of Agriculture "Luiz de Queiroz", Piracicaba, São Paulo).

Brito, J. O. (2000). Pró-carvão: Relatório sobre a cadeia produtiva de carvão vegetal e lenha do Estado de São Paulo. São Paulo: Sincal/Fcesp/Sebrae.

Chan, K. Y., \& Xu, Z (2009). Biochar: Nutrient properties and their enhancement. In J. Lehmann, \& S. Joseph (Eds.), Biochar for environmental management (1st ed.). Science and Technology. London: Earthscan.

Downie, A., Crosky, A., \& Munroe, P. (2009). Physical properties of biochar. In J. Lehmann, \& S. Joseph (Eds.), Biochar for environmental management (1st ed.). Science and Technology. London: Earthscan.

Falcão, N. P. S, Comerford, N., \& Lehmann, J. (2003). Determining Nutrient Bioavailability of Amazonian Dark Earth Solis-Methodological Challenges. In J. Lehmann, D. Kern, B. Glaser, \& W. Wodos (Eds.), Amazonian Dark Earths. Springer, Netherlands.

Falcão, N. P. S., \& Silva, J. R. A. (2004). Características de adsorção de fósforo em alguns solos da Amazônia Central. Acta Amazonica, 34(3), 337-342. https://doi.org/10.1590/S0044-59672004000300001

Fontes, P. J. P. (1994). Autossuficiência energética em serraria de Pinus e aproveitamento dos resíduos (Master's dissertation, Federal University of Paraná, Curitiba, Paraná).

Gautam, R. K., Mudhoo, A., Lofrano, G., \& Chattopadhyaya, M. C. (2014). Biomass-derived biosorbents for metal ions sequestration: Adsorbent modification and activation methods and adsorbent regeneration. Journal of Environmental Chemical Engineering, 2(1), 239-259. https://doi.org/10.1016/j.jece.2013.12.019

Glaser, B., Haumaier, L., Guggenberger, G., \& Zech, W. (2002). The "Terra Preta" phenomenon: A model for sustainable agriculture in the humid tropics. Naturwissenschaften, 88(1), 37-41. https://doi.org/10.1007/ s001140000193

Glaser, B., Lehmann, J., \& Zech, W. (2002). Ameliorating physical and chemical properties of highly weathered soils in the tropics with charcoal-A review. Biology and Fertility of Soils, 35(4), 219-230. https://doi.org/10.1007/s00374-002-0466-4

Goedert, W. J., Rein, T. A., \& Souza, D. M. G. (1990). Eficiência agronômica de fosfatos naturais, fosfatos parcialmente acidulados e termofosfatos em solo de cerrado. Pesquisa Agropecuária Brasileira, 25(4), 521-530.

Kämpf, A. N. (2000). Seleção de materiais para uso como substrato. In A. N. Kämpf, \& M. H. Fermino (Eds.), Substratos para plantas: A base da produção vegetal em recipientes. Porto Alegre: Gênesis.

Keiluweit, M., Nico, P. S., Johnson, M. G., \& Kleber, M. (2010). Dynamic molecular structure of plant biomass-derived black carbon (biochar). Environmental Science \& Technology, 44(4), 1247-1253. https://doi.org/10.1021/es9031419

Kern, D. C., Costa, M. L., \& Frazão, F. J. L. (2001). Evolution of the scientific knowledge regarding Black Earth soil in the Amazon. Yearbook of the Conference of Latin American Geographers. Spain, Benicassim. https://doi.org/10.1007/978-3-662-05683-7_3

Lehmann, C. J., Da Silva Jr, J. P., Rondon, M., Greenwood, J., Nehls, T., Steiner, C., \& Glaser, B. (2002). Slash and char a feasible alternative for soil fertility management in the central Amazon. Proceedings of the 17th Thailand: World Congress of Soil Science. Retrieved from https://pdfs.semanticscholar.org/ 4047/bd34182e80a0ba83413b16f77670b74e3dbd.pdf

Lehmann, J., Kern, D. C., German, L., Mccann, J., Martins, G. C., \& Moreira, A. (2003). Soil fertility and production potential. In J. Lehmann, D. C. Kern, B. Glaser, \& W. Woods (Eds.), Amazonian Dark Earths: Origin, Properties, Management. Dordrecht: Kluwer Academic Publishers. 
Liang, B., Lehmann, J., Sohi, S. P., Thies, J. E., O’niell, B., Trujillo, L., ... Luizão, F. J. (2010). Black carbon affects the cycling of non-black carbon in soil. Organic Geochemistry, 4(2), 206-213. https://doi.org/ 10.1016/j.orggeochem.2009.09.007

Liang, B., Lehmann, J., Solomon, D., Kinyangi, J., Grossman, J., O'neill, B., \& Neves, E. G. (2006). Black carbon increases cation exchange capacity in soils.Soil Science Society of America Journal, 70(1), 1719-1730. https://doi.org/doi:10.2136/sssaj2005.0383

Lima, I., \& Marshall, W. E. (2005). Utilization of turkey manure as granular activated carbon: Physical, chemical and adsorptive properties. Waste Management, 25(7), 726-732. https://doi.org/10.1016/j.wasman. 2004.12.019

Maekawa, K. (2002). Curso sobre produção de carvão, extrato pirolenhoso e seu uso na agricultura. APAN-Associação dos Produtores de Agricultura Natural.

Malavolta, E. (2006). Manual de nutrição mineral de plantas (1st ed.). São Paulo: Ceres.

Malavolta, E., Moraes, M. F., Lavres Júnior, J., \& Malavolta, M. (2006). Micronutrientes e metais pesados-essencialidade e toxidez. In E. Paterniani (Ed.), Ciência, agricultura e sociedade. Brasília: Embrapa Informação Tecnológica.

Mclaughlin, M. J., \& Singh, B. R. (1999). Cadmium in soil and plants. Dordrecht, Kluwer Academic. https://doi.org/10.1007/978-94-011-4473-5_1

Mituza, K., Matsumoto, T., Hatate, Y., Nishihara, K., \& Nakanishi, T. (2004). Removal of nitrate nitrogen from drinking water using bamboo powder charcoal. Bioresource Technology, 95(3), 255-257. https://doi.org/ 10.1016/j.biortech.2004.02.015

Mukherjee, A., Zimmerman, A. R., \& Harris, W. (2011). Surface chemistry variations among a series of laboratory-produced biochars. Geoderma, 3-4, 247-255. https://doi.org/10.1016/j.geoderma.2011.04.021

Nemati, M. R., Simard, F., Fortin, J. P., \& Beaudoin, J. (2015). Potential use of biochar in growing media. Vadose Zone Journal, 6(1), 1-8. https://doi.org/10.2136/vzj2014.06.0074

Pergeron, S. P., Bradley, R. L., Munson, A., \& Parsons, W. (2012). Physico-chemical and functional characteristics of soil charcoal produced at five different temperatures. Soil Biology \& Biochemistry, 58(1), 1-7. https://doi.org/10.1016/j.soilbio.2012.11.017

Prochnow, L. I. (2001). Eficiência Agronômica de fosfatos acidulados contendo compostos fosfáticos de ferro para o arroz de sequeiro e arroz inundado (Doctoral thesis, School of Agriculture "Luiz de Queiroz", Piracicaba, São Paulo). Retrieved from: https://bdpi.usp.br/item/001216727)

Raij, B. V. (2011). Fertilidade do solo e manejo dos nutrientes (1st ed.). Piracicaba: International Plant Nutrition Institute.

Resende, A. V., Neto, A. E. F., Alves, V. M. C., Muniz, J. A., Curi, N., Faquin, V., ... Carneiro, L. F. (2006). Fontes e modos de aplicação de fósforo para o milho em solo cultivado da região do cerrado. Revista Brasileira de Ciência do Solo, 30(3), 453-466. https://doi.org/10.1590/S0100-06832006000300007

Roberts, D. A., \& Nys, R. (2016). The effects of feedstock pre-treatment and pyrolysis temperature on the production of biochar from the green seaweed Ulva. Journal of Environmental Management, 169(1), 253-260.

Sanchez, P. A., Bandy, D. E., Villachica, J. H., \& Nicholaides, J. J. (1982). Amazon basin soils: Management for continuous crop production. Science, 216(4548), 821-827. https://doi.org/10.1126/science.216.4548.821

Santos, H. G. dos, Jacomine, P. K. T., Anjos, L. H. C. dos, Oliveira, V. A. de, Lumbreras, J. F., Coelho, M. R., ... Cunha, T. J. F. (2018). Sistema Brasileiro de classificação de solos (5th ed.). Brasília: Brazil.

Silva, E. C., Muraoka, T., Franzini, V. I., Alvarez Villanueva, F. C., Buzetti, S., \& Moreti, D. (2012). Phosphorus utilization by corn as affected by green manure, nitogen and phosphorus fertilizers. Pesquisa Agropecuária Brasileira, 47(8), 1150-1157. https://doi.org/10.1590/S0100-204X2012000800016

Silva, R. M. (2005). O Bambu no Brasil e no Mundo. Retrieved from http://www.embambu.com.br/imagens/ bambu_brasil_mundo.pdf

Sombroek, W., Kern, D., Rodrigues, T., Cravo, M. S., Cunha, T. J. F., Woods, W., \& Glaser, B. (2009). Terra Preta e Terra Mulata: Suas potencialidades agrícolas, suas sustentabilidades e suas reproduções. In W. G. Teixeira, D. C. Kern, B. E. Madari, H. N. Lima, \& W. Woods (Eds.), As Terras Pretas de Índio da 
Amazônia: Sua Caracterização e Uso deste Conhecimento na Criação de Novas Áreas. Embrapa Amazônia Ocidental.

Steinbeiss, S., Gleixner, G., \& Antonietti, M. (2009). Effect of biochar amendment on soil carbon balance and soil microbial activity. Soil Biology \& Biochemistry, 41(6), 1301-1310. https://doi.org/10.1016/ j.soilbio.2009.03.016

Van Zwieten, L., Kimber, S., Morris, S., Chan, K. Y., Downie, A., Rust, J., Joseph, S., \& Cowie, A. (2010). Effects of biochar from slow pyrolysis of papermill waste on agronomic performance and soil fertility. Plant Soil, 327(1-2), 235-246. https://doi.org/10.1007/s11104-009-0050-x

Woods, W. I., \& Mccann, J. M. (1999). The anthropogenic origin and persistence of Amazonian dark earths. Yearbook of Conference of Latin Americanist Geographers.

Xu, T., Lou, L., Cao, R., Duan, D., \& Chen, Y. (2012). Effect of bamboo biochar on pentachlorophenol leachability and bioavailability in agricultural soil. Science of the Total Environment, 414(1), 727-731. https://doi.org/10.1016/j.scitotenv.2011.11.005

Zimmerman, A. R. (2010). Abiotic and microbial oxidation of laboratory-produced black carbono (biochar). Environmental Science Technology, 44(4), 1295-1301. https://doi.org/10.1021 / es903140c

Zornoza, R., Moreno-Barriga, F., Acosta, J. A., Munoz, M. A., \& Faz, A. (2016). Stability, nutrient availability and hydrophobicity of biochars derived from manure, crop residues, and municipal solid waste for their use as soil amendments. Chemosphere, 144(1), 122-130. https://doi.org/10.1016/j.chemosphere.2015.08.046

\section{Copyrights}

Copyright for this article is retained by the author(s), with first publication rights granted to the journal.

This is an open-access article distributed under the terms and conditions of the Creative Commons Attribution license (http://creativecommons.org/licenses/by/4.0/). 